\title{
EGÉSZSÉGPSZICHOLÓGIAI MUNKA AZ ALAPELLÁTÁSBAN
}

Az alkalmazott egészségpszichológiai szakpszichológusok gyógyító tevékenységének egyik lehetséges és szükségszerűen megjelenő, ugyanakkor eddig kevés figyelmet kapott területe az alapellátás. Célom a hazai helyzet és a nemzetközi példák, jó gyakorlatok, ajánlások felsorakoztatásán kívül a külföldön már jól ismert és bizonyított alapellátási pszichológia (Primary Care Psychology) és az ehhez kapcsolódó kompetenciák bemutatása. A hazai és nemzetközi tapasztalatok alapján összegzem, miért van szükség az alapellátásnak pszichológusra, kitérek azokra a kompetenciákra is, melyekkel az alkalmazott egészségpszichológiai szakpszichológusnak akár önálló munkavégzésben, akár az alapellátó team tagjaként a hatékony munkavégzés érdekében rendelkeznie érdemes. Példaként bemutatok olyan elméleteket, melyeket a gyakorlati munkám során fontosnak tartok és meghatározzák az egészségpszichológiai gondolkodást. Az alkalmazott egészségpszichológiai szakpszichológus gyógyító tevékenységét háziorvosi praxisban rezidensként folytatott munkám egyik esetén keresztül mutatom be.

A magyar lakosság egészségi állapota más európai országgal való összehasonlításban jelentős elmaradást mutat. Ennek hátterében részben az életmóddal összefüggő, krónikus betegségek egyre gyakoribb megjelenése és nem megfelelő kezelése áll, melyek kialakulásában az életmód tényezők közül a pszichés jóllétnek, lelki egészségnek is döntő szerepe van. A lelki egészség az egyén életminőségének egyik pillére és az egészségben eltöltött életéveinek feltétele is (Csabai \& Kis, 2017).

Kovács és Mészáros (2006) szerint minden tizedik ember, aki háziorvosához fordul, pszichés tünetektől szenved. Ezek a betegek jellemzően különböző testi tünettel keresik fel háziorvosukat, mely tünetek mögött vagy mellett bizonyítottan valamilyen pszichés probléma vagy betegség áll. A háziorvosnak egy betegre mindössze átlagosan 6 perce jut. Az idő hiánya és az orvosok döntően szomatikus szemlélete jelentősen megnehezítheti a problémák felismerését (Torzsa et al., 2017). Bizonyára ez is hozzájárul ahhoz, hogy sok háziorvos gyógyító munkájának hangsúlya nem a betegségmegelőzésen, hanem a betegellátáson van. A pszichológiai gyógyító munka, a testi tünetekben megjelenő pszichés problémák felismerése elsősorban a pszichológus szakemberek feladata és kompetenciája, de a tünetképződés komplex folyamatainak megértéséhez és a gyógyításhoz is integrált, közös munkára van szükség. 


\section{PSZiChOLÓGUSOK AZ ALAPELLÁTÁSBAN: EGY HAZAI MÓDSZERTANI FEJLESZTÉS TANULSÁGAI}

Magyarországon az SH/8/1 regisztrációs számú Svájci Hozzájárulás keretében támogatott $A z$ egészségügy forrásainak felhasználásával népegészségügyi fókuszú alapellátás-szervezési modellprogram Virtuális Ellátó Központ támogatásával címü program (úgynevezett Svájci Modellprogram) keretében valósult meg elsőként pszichológus szakemberek bevonása az alapellátásba. A 2013 és 2017 között zajló program háziorvosok együttmüködésével és egyéb szakemberek mellett pszichológusok közreműködésével növelte és egészítette ki az alapellátás kompetenciáját és hatáskörét. A modellprogram közel 5 évig tartott Észak-Magyarország és az Észak-Alföld térségében, négy praxisközösségben (Jászapáti, Heves, Borsodnádasd, Berettyóújfalu). A négy praxisközösség új többletszolgáltatásokat (egészségi állapotfelmérés, életmód tanácsadás, gyógytorna, dietetika, egészségpszichológiai szolgáltatás, prevenciós rendelés, közösségi egészségfejlesztő programok) nyújtott különböző szakemberek bevonásával a helyi lakosság számára (Martos et al., 2017).

Cseh és munkatársai (2021) Praxisközösségi modellprogramok tapasztalatai és aktualitásai címü cikkükben leírják, hogy a Svájci Modellprogram során megalakult praxisközösségek müködési módszertanát alapul véve, az Európai Unió által finanszírozott projektek keretében 2018-ban 45 praxisközösség, 2019-ben pedig még 6 praxisközösség kezdte meg müködését az ország 128 településén, 600 ezer föt ellátó területen a Nemzeti Népegészségügyi Központ koordinálásában. A program során - egyéb szolgáltatások mellett - egyéni vagy csoportos pszichológiai foglalkozásban részesült összesen 72 ezer fó és 65 ezren vettek részt prevenciós tanácsadáson. 2019 és 2021 időszakában a Három generációval az egészségért programok során újabb 143 konzorciumi praxisközösség alakult meg, melyek szakmai tevékenységének fókuszába célzottan a krónikus betegségek szürési-gondozási tevékenysége került. A programban szintén jelen voltak pszichológus szakemberek. A szerzők cikkük összefoglalójában a praxisközösségi müködésforma - 8 éves eredményeit alapul véve -, mint a magyar egészségügyi alapellátás fejlesztésének alappillére mellett érvelnek. Kifejtik, hogy a praxisok népegészségügyi és más egészségügyi szakemberekkel bővülve egészségfejlesztési és prevenciós szemléletű programokat képesek megvalósítani, a lakosság számára hiánypótló többletszolgáltatások elérésével (pl.: egészségpszichológia) multidiszciplináris csapatmunka keretében. A praxisokba bevont pszichológus szakemberek által gondozott betegek pedig hamarabb kerültek stabil állapotba vagy gyógyultak meg, ez az állapot hosszabb ideig volt fenntartható és a háziorvosi konzultációk száma is jelentősen csökkent (Martos et al., 2017).

$\mathrm{Az}$ alkalmazott egészségpszichológiai szakpszichológus képes támogatni az egyént, hogy ismerje fel és tudatosítsa saját szerepét és felelősségét betegsége kialakulásában és lefolyásában. A szakember segítségével a beteg képes megküzdeni a diagnózis tényével, 
javulhat öngondoskodása és felismerheti az orvossal való hatékony együttműködés fontosságát a gyógyulása folyamatában vagy az állapota megfelelő szinten tartásában. Krónikus betegségek esetén az orvos számára jelentős időmegtakarítást jelenthet, a sokszor direktív orvosi betegvezetést pedig kiegyensúlyozza az elfogadó, egészségorientált és pszichoterápiás attitűddel. Segíti az egyén betegséggel kapcsolatos vélekedésének, reprezentációinak azonosítását és feldolgozását. Támogatást nyújt az életmódváltással kapcsolatos készségek kialakításában, a viselkedés fenntartásában. Esetleges állapotromlás esetén széleskörủ információval tud szolgálni az orvos számára a családi és egyéb életkörülményeket illetően. Képes felismerni és kezelni a betegség mögött meghúzódó kognitív disztorziókat és diszfunkcionális attitüdöt. Azonnal hozzáférhető és hatékony segítséget tud nyújtani azokban a helyzetekben, amikor az orvos nyugtatót vagy altatót írna fel és szükség esetén klinikai szakpszichológus bevonását kezdeményezi. Az alkalmazott egészségpszichológiai szakpszichológusnak fontos szerepe van a gyógyító csapat kommunikációjának támogatásában, a konfliktus - és stressz kezelésében, kiégés prevenciójában is (28/2017. (X. 25.) EMMI rendelet 5. melléklet).

\section{NEMZETKÖZI KITEKINTÉS}

A segítő hivatású szakemberek számára a folyamatos szakmai fejlődés biztositásához, a sikeres munkához alapvető a külföldi gyakorlatok ismerete és átvétele is.

A KPMG - The Nuffield Trust (2014) szakértőinek eredményei szerint jellemző trendként írható le az európai országokban, hogy az alapellátás tevékenységi körének fejlesztése a prevenciós szemlélet felé halad. Szakértők a megelőzés, egészségfejlesztés szerepének jelentőségét emelik ki, amit egyrészről orvosszakmához kapcsolt társszakmák alapellátásba történő bevonásával, azokkal szoros együttműködésben valósítanak meg. Számos országban, például Hollandiában, az Egyesült Királyságban, Dániában és Finnországban is jelen vannak az alapellátásban pszichológusok, jelentős terhet átemelve a szakellátásról. Az összefoglaló szerint az alapellátás fejlesztéséről akkor beszélhetünk, ha az alapellátásban a prevenciós és népegészségügyi-egészségfejlesztési szolgáltatások hangsúlyt kapnak, az egyes szakorvosi és közösségi szolgáltatásokkal összekapcsolódnak, valamint a betegek és kifejezetten a hozzátartozók kezelésbe való bevonása és a betegek saját felelősségének szerepe megjelennek. Ezek a reformtevékenységek azon túl, hogy az ellátó hatékonyabb működését segítik elö, a pszichés betegségek kialakulásának megelőzését és az azokkal való együttélés támogatását is segítik (Edwards et al., 2014).

Az Európai Bizottság 2014-es alapellátás helyzetéről szóló összefoglaló riportjában szintén az alapellátás szolgáltatás rendszerének bővítése, valamint közösségi funkciójának erősítése mellett érvel. Véleményük szerint ez elősegítheti a mentális egészségügyi, otthoni és a szociális ellátások integrációját, a betegek stabilabb illeszkedését a társadalomba, valamint lehetőséget teremt olyan társszakmák megjelenésére az alapellátásban, 
melyek egyébként nem kifejezett részei a formális egészségügyi ellátásnak. Leírják, hogy ilyen szakemberek például a pszichológusok (Brouwer et al., 2014).

Gunn és Blount (2009) a pszichológia egyik új irányaként, elsőként vázolnak fel egy olyan alapellátási modellt - mentális alapellátás néven (Primary Care Mental health) -, melyben a lelki egészség megőrzése és védelme kifejezett hangsúlyt kap. A legtöbb országban a pszichés problémák képezik az alapellátás munkaterhelésének jelentős részét. A szerzők kifejtik, hogy az egészségügyi rendszer egészét tekintve a lelki egészség megőrzésére irányuló szolgáltatásoknak elsősorban az alapellátás felől kellene kiindulniuk. A szerzők egy integrált, összehangolt modellt javasolnak, ahol a pszichológusok (egészségpszichológusok és klinikai pszichológusok) az alapellátást végző orvosi csapattal együttműködve dolgoznak. A modell lehetővé teszi, hogy a pszichológusok olyan betegeket tudjanak ellátni, gyógyítani, akik egyébként máshogyan nehezen vagy egyáltalán nem jutnának el szakemberhez (időskorúak, szomatikus panaszokkal küzdők, krónikus betegek). Az integrált modell lényege tehát az orvosokkal folytatott folyamatos konzultáció és kommunikáció, szakmai teamek formájában.

Haas (2004) Handbook of Primary Care Psychology címü kézikönyvének első fejezetében arról ír, hogy az alapellátásnak azért van a leginkább szüksége pszichológiai szolgáltatásokra, mert egyre növekvő számmal vannak jelen a kezeletlen pszichés betegségek, valamint az életmód- és viselkedésbeli problémák száma is folyamatosan növekszik, a krónikus betegségek pszichológia tényezői pedig szintén markáns hatást gyakorolnak a betegséggel élőkre. Véleménye szerint az alapellátást rendszeresen igénybe vevő egyéneknek van a legnagyobb szükség pszichológusra. Leírja, hogy minden tünetként jelentkező klinikai probléma alapvetően viselkedéses probléma. Abból a tényből kiindulva, hogy a legtöbb pszichiátriai gyógyszert (pszichotróp szerek 80\%-a) az Egyesült Államokban nem pszichiáterek írják fel, hanem alapellátást végző orvosok, az alapellátást az Egyesült Államokban de facto mentális egészségügyi rendszernek tekinti. A tünetek enyhíthetők és megfelelő szinten tarthatók, ha bizonyítékokon alapuló egészségpszichológiai és klinikai pszichológiai módszereket alkalmaznak a kezelés során. A szerző megjeleníti az alapellátási pszichológus (Primary Care Psychologist) szakember személyét is. Leírja, hogy az alapellátási pszichológus sikeres munkájának lényege és kulcsa az együttműködés. A szerző leírja azt is, hogy az alapellátási pszichológusnak széleskörü ismeretekkel kell rendelkeznie a közösségi erőforrások tekintetében. Fontos, hogy a pszichoterápiás módszereken túl tájékozott legyen további eljárásokban is, mint a pszichoedukáció vagy a támogató-csoportok.

Az Angol Pszichológiai Társaság Egészségpszichológia Szekciójának útmutatója szintén bemutatja az egészségpszichológus alapvető szerepét. Megfogalmazzák, hogy az egészségpszichológus olyan pszichológiai ismeretek alkalmazásában jártas, melyek segítségével képes kialakítani, megtervezni krónikus betegek esetében az öngondoskodás fejlesztésére irányuló beavatkozásokat, képes támogatni az egészségmagatartás kialakítását, valamint segíti a káros magatartási formák és szokások elhagyását. Munkájuk során 
együtt tudnak működni háziorvosokkal, népegészségügyi - és kórházi szakemberekkel, betegekkel, azok hozzátartozóikkal és szakmai szervezetekkel is. Végezhetik fizikai tünetekkel rendelkező betegek hosszú távú gondozását és az önmenedzselésük támogatását. Dolgozhatnak önállóan vagy csapatban, végeznek egészségfejlesztést és támogatják a káros viselkedésformák megváltoztatását. Képesek javaslatot tenni az egészségügyi ellátás fejlesztésére, szakemberek és laikusok számára egyaránt tarthatnak tájékoztatást és tanácsadást, kutatómunkát végezhetnek és mindennapi munkájukat tudományos evidenciákra építhetik. Oktatással és kommunikációval is foglalkoznak, munkájukkal támogatják az alapellátást (háziorvost) és a közösségi szolgáltatásokat. Mütétek előtt felkészíthetik a betegeket a beavatkozás pszichés terheivel való megküzdésre, ezzel támogatva a rehabilitációs során a bizalom kialakulását orvos és beteg között. Véleményük szerint az egészségpszichológus képes a népegészségügyi szűrőprogramokat is hatékonyan támogatni (pl.: szűrések kommunikációja), de egészséges életmódot hirdető megmozdulásokat, helyi közösségekben pedig egészségfejlesztési célú beavatkozásokat is tervez. Támogatja a dohányzásról való leszokást, a megfelelő étrend kialakítását, a stressz és a függőségek leküzdését (The British Psychological Society).

Gatchel és Oordt (2003) arról írnak, hogy hogyan tud, illetve hogyan érdemes együttműködnie az egészségpszichológusnak az alapellátás többi szereplőjével. Hangsúlyozzák, hogy az alapellátás jellegéből adódóan lényegesen más környezetet jelent, mint amelyben a pszichológusok általában dolgoznak. Éppen ezért van szükség az együttmủködés más módjára, új készségek meglétére és kialakítására. Az új helyzethez mind a szakembernek, mind a környezetének alkalmazkodnia kell, ami nagymértékben függ a kollégák közötti stabil, bizalmi kapcsolattól. A pszichológusnak érdemes megismernie a személyzetet is (pl.: betegirányító), mivel tőle is függ a saját munkája. Ha mind a szakmai, mind a támogató személyzet megismeri a pszichológus munkáját, annak értékét és szerepét, több motivációjuk lesz arra, hogy támogassák és együttmüködjenek vele. Fontos, hogy ennek érdekében a pszichológus rendszeresen konzultáljon kollégáival, kezdeményezze ezeket az alkalmakat, legyen elérhető és törekedjen a szakmai együttmüködésre.

Magyarországon is - ahogyan azt a fenti, számos külföldi példa bizonyítja -, legközvetlenebbül és a legszélesebb sávban a háziorvosi rendszer keretében válhatna elérhetővé a pszichológiai szolgáltatás. Mivel a rendszer már jól kiépített és mindenki számára elérhető, így hazánkban is az ellátás ezen szintjén lehetne a legtöbbet tenni a lakosság testi-lelki jóllétéert. Ennek egyik pillére a pszichológiai többletszolgáltatások megjelenése. A pszichológus szakember hatékony munkavégzéséhez azonban, ahogyan arra Cseh és munkatársai (2021) utalást tesznek, idő-és forráskorlát nélküli pozícióra, magasabb megbecsültségre van szükség. Sürgető tehát a tapasztalatok felhasználása és megalapozott implementációja alapján valódi, napjaink klinikai irányelveinek megfelelö, nemzetközi szinten már működő és bizonyított, széles hatáskörủ alapellátási szolgáltató 
rendszer kialakítása, ahol a multidiszciplináris csapat által nyújtott többletszolgáltatások nem egy időszakra, hanem hosszútávon, normatívából kerülnek finanszírozásra.

A fent példaként bemutatott külföldi gyakorlatokból kitűnik, hogy ezekben az országokban alapvetően prevenciós szemléletben, társszakmák bevonásával - multidiszciplináris szemléletben - nyújtott többletszolgáltatások biztosításával működik az alapellátás, ahol minden esetben a szakmai csapat tagja az egészségpszichológus és/vagy a klinikai pszichológus. Másrészt az is nyilvánvaló, hogy a krónikus betegségek komplex, interdiszciplináris szemléletben történő gondozása egyes országokban már évtizedes múltra tekint vissza, biztosítva ezzel a pszichés problémák idejében történő felismerését és kezelését. A komplex, integrált szemlélet jól képzett, kiválóan együttműködni képes alapellátó szakemberek jelenlétét teszi szükségessé, ahol nem csak a pszichológustól várható el lélektani érzékenység és a komplex szemléletre való nyitottság.

\section{PSZICHODINAMIKUS ELMÉLETEK ALKALMAZÁSA AZ ALAPELLÁTÁSI MUNKáBAN}

Bálint Mihály magyar pszichoanalitikus, a háziorvosi munka pszichológiai támogatását megalapozó klasszikus elmélet és gyakorlat megalkotója. Egyik főbb elgondolása és célja volt a pszichoterápia elveinek gyakorlati alkalmazása a mindennapi orvosi gyógyító munka során. Bálint a testi tünetek megjelenését többek között tárgykapcsolati konfliktusokkal hozta összefüggésbe, így azok kezelésében tárgykapcsolati elveket, elméleteket is alkalmazott (Bálint, 1957, idézi Csabai, 2010). A háziorvosi praxisban, kliensekkel folytatott saját munkám történései és tapasztalatai hátterében gyakran véltem felismerni korai, tárgykapcsolati mintákat és összefüggéseket, melyek egybevágtak a "pszichoszomatikus integráció modellben”leírtakkal (Stephanos, 1975). A modell bemutatása előtt fontos említést tennem a Stephanos (1975) által leírt „pszichoszomatikus jelenségról” is, amely az integrációs modell lélektani alapja. Ennek értelmében trauma vagy fokozott stressz hatására jellemző az egyénre a visszavonultság, a befelé fordulás, az energiák „takarékon” való működtetése és a kapcsolatok beszűkítése. Ez a regresszív állapot a korai tárgykapcsolati-kötődési, szomatikus mintázatok megjelenését aktiválja. Súlyos regresszióban a beteg akár visszakerülhet a koragyerekkori duálunió vágyának állapotába, amely jelentősen befolyásolja a gyógyító szakemberrel való kapcsolatát is (Stephanos, 1975).

A testi tünetképzés egyik fö jellegzetessége, hogy a szomatikus tünet és a pszichés konfliktus között pszichoszomatikus zavar esetén hasítás jön létre. Ez a viselkedés szintjén azt jelenti, hogy a páciens vagy csak a testi tüneteiről, vagy csak a lelki problémáiról panaszkodik (Manolopoulos, 2006). A kezelő orvos és egyéb személyzet a beteg verbális hozzáférhetetlensége és érzéseinek kifejezési nehézségei miatt frusztrációként élheti meg, ha a beteg elsősorban fizikai panaszairól számol be. Azonban éppen ezek a pszichodinamikai folyamatok világítanak rá a pszichológus szerepére, tárgykapcsolatokra gyakorolt hatására. Ezzel a jelenséggel gyakran találkozom munkám során. A kliens érzé- 
seitől, lelki állapotától függetlenül számol be testi tüneteiről és csak néhány esetben találkozom tudatos kapcsolattal a fizikai tünetek és az érzelmek között. Közös munkánk első lépése a pszichoszomatikus integráció modell értelmében a bálinti „elsödleges tapasztalati tér" kialakítása (Bálint, 1957). Ennek jellemzője a biztonságos, a kliens számára kiszámítható kapcsolat, mely megteremti azt a közeget, ahol a traumatikus eseményhez az üléseink előrehaladtával verbalizálható érzések és gondolatok kapcsolódnak. A kliens a történtek újbóli felidézésén és érzései megfogalmazásán keresztül egy újabb, biztonságos térben felszabadulhat a trauma nyomasztó hatása alól. A közös munkánk során létrejövő, úgynevezett "flash”(,villanás”), egy érzelmi kapcsolat lehetővé teszi, hogy a kliens összefüggést találjon a negatív érzései és a testi tünetei között (Bálint, 1957). Megértheti, hogy gátlásai miként járulnak hozzá kapcsolati zavaraihoz, ezáltal testi tüneteihez és felismerheti, hogy a kapcsolataiban bekövetkező érzelmi változások a betegség kimenetét, a gyógyulását is meghatározzák. A testi tünetektől szenvedő betegeknél a pszichológus feladata nem a tünetek tudattalan, mögöttes okainak analitikus feltárása, hanem az elsődleges, biztonságot nyújtó tapasztalati tér, egy empatikus kapcsolat kialakítása, ahol a beteg a ,flash"létrejöttével újraélheti, újra értelmezheti tapasztalatait, érzéseit és a terapeutával kialakult biztonságos kapcsolat mintájára alakíthatja saját interperszonális viszonyait is. Az új, magasabb szintủ érzelmi és tárgykapcsolati működés pedig segíti gyógyulását és lelki egészsége megőrzését (Balint \& Norell, 1973, idézi Csabai, 2010).

Minden gyógyító, de főként a praxisközösségben dolgozó szakemberek munkája akkor hatékony, ha a kliensek állapotáról szóló tájékoztatás, annak megosztása egymás között folyamatos és a gyógyító csapat tagjai hasonló attitűddel fordulnak a kliens felé. Ezzel támogatva őt a függő, regresszív énjének elhagyásában és egy új, önálló identitás, a gyógyulását támogató tárgykapcsolat kialakításában.

Az orvos-beteg találkozások alkalmával érdemes megfigyelni a szintén Stephanos (1980) által leírt epizódok technikát is, ami alapvetően osztályos (fekvőbeteg szakellátás) kontextusban, de az alapellátásban is megfigyelhető főként önállótlan, társkapcsolataiban bizonytalan klienseknél. A kliensek a gyógyító csapat egyes tagjaival történt interakcióinak történései párhuzamba állíthatók személyes életükben éppen aktuális eseményeivel, vagyis epizódokkal. Azoknak a klienseknek, akik kezdetben frusztrációt, szorongást éltek át a személyzettel való találkozások (pl.: kontroll, gyógyszerírás) alkalmával, a pszichológus és a vele való kapcsolat jelentette a biztonságos, megtartó átmeneti tárgyat, melynek segítségével a beteg megélhette szorongását. Az általam látogatott háziorvosi praxisban az orvos általános betegellátást végez, az ápolóhoz pedig főként receptért várakoznak a betegek. Többször megfigyelhető, hogy a betegek általuk jelentéktelennek vélt panaszaikkal nem az orvost, hanem a nővért keresik fel. A jelenségnek egyéb oka is lehet, de a klienseim esetében valószínűnek tartottam, hogy a páciens apával vagy más autoriter személlyel való konfliktusa a háziorvosra vetült, így az ápoló mint édesanya - a biztonságot jelentő tárgyként volt jelen. 
Összességében azt gondolom, hogy a "pszichoszomatikus integráció modell” hatékonyan alkalmazható a praxisközösségi munkában és a "flash” vagy az „epizódok" technika pszichodinamikai értelemben szintén hozzájárulnak a beteg tárgykapcsolatainak megértéséhez, tükrözéséhez. Azonban a testi tünetek kezelése, a terápiás munka sokkal hatékonyabb - a feltáró, analitikus terápiával ellentétben - a bio-pszicho-szociális, komplex szemléletű terápiás technikán keresztül, mert viszonylag rövidebb idő alatt érhető el a tünetek csökkenése és egy tudatosabb életforma kialakítása.

\section{A BETEGSÉGREPREZENTÁCIÓK FELTÁRÁSÁNAK JELENTŐSÉGE AZ ALAPELLÁTÁSI MUNKáBAN}

Az egészségpszichológiában széles körben kutatott terület a betegségreprezentációk hatásának vizsgálata a különböző betegségek lefolyására. A betegségreprezentációnak kiemelkedő szerepe van a krónikus betegségekhez történő alkalmazkodásban, az azzal járó tünetek megértésében (már a tünetek megjelenésének kezdetén is) és a gyógykezelés folyamatában mutatott együttműködési hajlandóság mértékében (Leventhal et al., 1980). Az egyén betegséggel kapcsolatos hiedelmeinek vizsgálatával és az egészséggel kapcsolatos kognitív reprezentációk kérdéskörével elsőként az 1970-es években kezdtek el foglalkozni egészségpszichológiai kutatások. Leventhal és munkatársai (1980) írták le a betegségkogníció fogalmát. Véleményük szerint a betegek implicit betegségelméleteket alakítanak ki a tüneteik észlelésekor és értékelésekor. A betegségreprezentációk olyan kognitív reprezentációkat vagy sémákat jelölnek, melyek az észlelt tünetek, a gyógyulás és a betegségek területén szerzett korábbi tapasztalatokból származnak és meghatározzák az információfeldolgozást (Leventhal et al., 1980). Leventhal és munkatársai (1984) a fenyegető élethelyzetekkel való megküzdés folyamatát bemutató, „önszabályozási modellje" a kultúrát, a nyelvet és a szociális szerepeket mint változó tényezőket is figyelembe veszi. A megküzdési folyamat első lépéseként megjelennek az egészséget fenyegető külső és belső ingerek és információk kognitív reprezentációi. A folyamat második lépése a betegség észlelése után az annak megfelelő, kialakult élethelyzethez alkalmazkodó cselekvési, megküzdési terv kialakítása, amely már a létrejött kognitív reprezentációkon alapul. A harmadik lépésben pedig az eredmények kiértékelése történik meg, amely eredményezheti a korábbi megküzdési viselkedés felülírását is, amennyiben az nem vezetett eredményre. Tehát a rendszerben egy visszacsatolási mechanizmus is működik. Fontos, hogy a kognitív szabályozó kör mellett párhuzamosan egy emocionális szabályozó-rendszer is jelen van a megküzdési folyamatban, mivel egy betegség által előidézett vészhelyzet - a kognitív mellett - emocionális választ is eredményez. Tiringer és munkatársai (2007) szerint az egyéni reprezentációk befolyásolják, hogy az egyén mennyire válik aktív közreműködőjévé saját kezelésének, miként észleli tüneteit, hogyan képes azokhoz alkalmazkodni és hogyan küzd meg velük, emellett egyéni reprezentációi befolyásolják a tünetekre, betegségre adott pszichés és viselkedéses reakcióit is. 


\section{5. „NEM TUDOM, MIT TUDNÉK KEZDENI EZZEL A F́́JDALOMMAL”. ESETISMERTETÉS A HÁZIORVOSI ELLÁTÁS TERÏLETÉRŐL}

Judit 33 éves, képzőművész. Egy alföldi kisvárosban született, férjével 8 éve Budapesten élnek. Másfél éve fennálló gyomortáji, hasi fájdalom miatt keresi fel ismét háziorvosát, vizsgálati eredménnyel érkezik a rendelőbe. Háziorvosa meglátása szerint diffúz hasi panaszai összefügghetnek pszichés problémákkal. Judit ezzel egyetért, az orvosi kontrollt követően háziorvosa a szobámhoz kíséri. A friss vizsgálati eredmény szerint Judit vérmintájában a vizsgált tumormarkerek közül a CA19-9 szintje kissé emelkedett volt. Ez valójában egy rák antigén, amelynek nagyobb mennyiségủ megjelenése rosszindulatú daganat jelenlétére utalhat. Azonban más betegségek (pl. epekövesség, hasnyálmirigygyulladás, cisztikus fibrosis vagy különböző májbetegségek) esetén is emelkedhet a szintje. A CA 19-9 kis mennyiségben megtalálható egészséges emberben is. Juditnak jelenleg várakoznia kell a 2 hónappal később esedékes ultrahang vizsgálatra, amely alapján kiderülhet a pontos diagnózis. Testi fájdalmait és az állapotával kapcsolatos bizonytalanságot nehezen viseli, ezért is döntött háziorvosa pszichológus bevonása mellett.

Judit a tünetek miatti fájdalom következtében meggyötörten ült a folyosón. Amikor megláttam, sajnálatot éreztem iránta és átéreztem a testi fájdalmait. Felmerült bennem a kérdés, vajon mi okozza testi tüneteit, mi lehet a fájdalma hátterében és miért ennyire elkeseredett, amikor valójában nem tud még pontos diagnózist. Talán volt már a családjában emésztőrendszeri betegség? Megfogalmazom magamban, hogy családi anamnézis tekintetében széleskörủen kell explorálnom annak érdekében, hogy fel tudjam tárni a félelme okát.

Judit alacsony, vékony, szikár testalkatú. Haja hosszú, fekete, amit minden ülés alkalmával hátul összekötve visel. Arca kissé sápadt. Testtartása félelmet, szorongást sugall, kezét összefonja az ölében, lábát mindvégig keresztben tartja. Elmondása szerint kissé megijedt a helyzettől, nem volt korábban pszichológusnál. Ennek ellenére hamar kialakul a rapport, és mesélni kezd az állapotáról. Véleménye szerint a tünetei a stresszel lehetnek kapcsolatban. Leküzdhetetlen idegességet érez, egyszerüen nem tud megnyugodni. Azt mondja, leginkább a ráktól fél. Az első ülésünk alkalmával beszámol arról, hogy a gyomorfájdalom életvitelbeli akadályokat is okoz számára. Sokszor inkább nem eszik, kihagyja a társas étkezéseket, mert fél a fellépő fájdalom tól. Nyaralás alatt, amikor többet tudott pihenni, szinte tünetmentes volt, élvezni tudott minden programot. A gondolatelterelés módszere eddig bevált stresszkezelési technika volt számára, próbálta lefoglalni magát nyaralással, a munkájával, hobbijával, de most úgy érzi, ez már nem vezet eredményre, tünetein nem tud úrrá lenni. Gyakran felkel éjjel, zavaró gondolatok gyötrik, nem tud aludni. Beszámol arról is, hogy a családjában volt már több gyomorés bélrendszeri betegség, ami miatt megalapozottnak tartja félelmét. Édesanyjánál korábban fekélyt diagnosztizáltak, édesapja örökletes eredetủ vékony gyomorfallal, nagymamája pedig hasnyálmirigy gyulladással élt. 
Az első interjú végén átbeszéltük, mit szeretne elérni, miért szeretne pszichológushoz járni. Meglátása szerint sokkal lazábban kellene vennie a dolgokat. Görcsösen meg akar felelni, amit barátai és családja is jeleztek már neki. Elmondása szerint a szakmai életben is a saját maga által kitűzött, sokszor irreális elvárásokat „kergeti”. Saját maga túlzó elvárásainak szeretne megfelelni és nem tud ezekből az elképzelésekből engedni. Szorongásán, félelmein szeretne úrrá lenni és alacsony stressztűrő képességét szeretné fejleszteni. Kérésként fogalmazza meg felém azt is, ha a közös munkánk során felszínre kerülne egy régi trauma, vagy fel nem dolgozott esemény, jelezzem számára, mert tudni akarja, mi a tünetei okozója. Ekkor arra gondolok, hogy Judit valóban minden erejével és a legnagyobb elszántsággal akar gyógyulni és elhagyni végre a testi fájdalmait. Megfogalmazódik azonban bennem a kérdés, hogy milyen negatív életeseményre, milyen veszteségre gondolhat, ami a betegsége hátterében állhat. Arra gondolok, esetleg tudja is, milyen történés lehet összefüggésben a tüneteivel, de eszköztelennek érzi magát ahhoz, hogy szembenézzen vele.

\subsection{A TERÁPIA MEGKEZDÉSE}

Az első ülés tapasztalatai alapján Judit láthatóan motivált a közös munkára. Testi tünetei megnehezítik a mindennapjait, és több célt is megfogalmazott önmagára vonatkozóan. Az első találkozás végén elmondom, hogy 10 ülésre van lehetőségünk, amelyre meg is kötjük a terápiás szerződést. Elmondom, hogy titoktartás kötelez, üléseinkről harmadik fél számára információt nem adok ki. A háziorvosával megkezdett konzultációt pedig kizárólag a szakorvosi vizsgálat eredményei miatt és a közös munka során elért célokkal kapcsolatosan tartom fent. Beszélek arról is, hogy közös munkánk fontos része a pontos diagnózisról való tájékozódás. Meg kell ismernünk vagy kizárnunk a testi tüneteket okozó lehetséges szervi elváltozást, mivel ennek megfelelően választom meg az alkalmazott terápiás eszközöket. Ezek segítségével Judit csökkenteni lesz képes a mindennapi feszültséget, hatékonyabbá válik az életesemények fogadásában és feldolgozásában, ami hosszú távon életminőségének javításához és egészségi állapotának megőrzéséhez járulhat hozzá.

Célok:

- betegségreprezentációk feltárása, testi érzések verbalizálása,

- a kliens önmagához való viszonyának tisztázása, önismeret növelés,

- hatékony stresszkezelési módszer alkalmazása.

Eszközök:

- autogén tréning,

- Rövid Betegségpercepció Kérdőív (BIPQ).

A második találkozáskor megkérdezem, hogyan érezte magát az első ülésünk után, milyen gondolatai voltak. Arról számol be, hazaérkezve elmesélte férjének, hogy pszi- 
chológushoz irányították. Már régen foglalkoztatta a gondolat, hogy érdemes lenne tüneteivel egy szakembert felkeresni. Ebben férje is támogatta. Korábban már javasolták számára az autogén tréninget és a jógát is, de akkor elszalasztotta ezeket a lehetőségeket. Elmondja, hogy az első találkozás után kettősséget érzett. Egyrészt nagyon feszült volt, mikor a vérvétel eredményével érkezett háziorvosához és aznap rendkívül gyötörték hasi tünetei is. Az eseményekre visszagondolva ma már tudja, hogy tüneteit akkor is a stressz okozta. Másrészt érzett egy kis megkönnyebbülést is, mert arra gondolt, végre beszélhet egy szakemberrel.

\subsection{AZ APA ELVESTTÉSE - AZ ELAKADT GÝ́SZFOLYAMAT SEGíTÉSE}

Judit elmondja, hogy gyomortünetei 3 évvel ezelőtt, édesapja halála után jelentkeztek. Ekkor arra gondolok, hogy nagy valószínűséggel ez lehet az az életesemény, amire korábban utalt. Édesapja halála után sokat aggódott azon, miként fog „felállni” a családi rend, hogyan rendeződnek a családi viszonyok, édesanyja hogyan tudja kezelni a helyzetet, és azt sem tudta, hogyan rendezze ezt el saját életében. Úgy gondolta, az idő majd rendezi, de halottak napján nem tudott kiszállni az autóból és a sírhoz menni, mert annyira zokogott. Apai nagymamája édesanyjával él egy háztartásban szülővárosában. Elmondása szerint a nagymamája és az édesanyja nem jöttek ki jól egymással. Folyamatos feszültségről számol be köztük, ahol az édesapa volt az „ütközőpont”. Judit a szülei között gyakran érzett és látott feszültséget a nagymama piszkálódásai miatt. Megosztja velem azt az emlékét, mikor édesanyja a konyhában volt, édesapja pedig a szobában, és nem hallotta egymáshoz szólni őket napokig. Majd folytatva az emlékezést elmondja, hogy édesapja halála után sokat aggódott azon, édesanyja hogyan tudja kezelni az új helyzetet, hogyan fog tudni együtt élni a nagymamával. Visszagondolva most úgy látja, a kezdeti néhány hónap volt nagyon nehéz, de mostanra nyugalmat lát köztük, ami véleménye szerint az édesanyán múlt. Az elején mindkettőjüknek szembe kellett nézni azzal, hogy a legfontosabb embert vesztették el az életükben, de már tudnak beszélgetnek egymással erről is. Számára is még mindig a legfájdalmasabb esemény édesapja elvesztése. Ekkor hangja elcsuklik, sírni kezd, és elmondja, édesapja hirtelen, minden előzmény nélkül a munkahelyén hunyt el. Remegni kezd, mikor erről beszélünk. A terápia ezen pontján felszínre került egy fel nem dolgozott veszteség, amelynél megállunk, szeretném megtudni jelenleg hol tart a gyászmunkában. Magamban azzal a feltételezéssel élek, hogy Judit a gyászfolyamatban elakadt. Az édesapja halálát követő időszakban a figyelme nem saját magára irányult, nagy fizikai és lelki erőt kívánt tőle az édesanyja és nagymamája közti viszony alakulása, annak hatása saját életére. Igyekszem megtudni, ki volt ezekben az időkben Judit valódi támasza, kire számíthatott, hogyan érzi most magát a családjában. Néhány ülés alkalmával édesapjával való kapcsolatáról beszélünk. Az emlékek alapján egy egészséges, szeretetteljes apa-lánya viszony jelenik meg elöttem. Színes gyermekkori élményekkel, féltő fiatal felnőttkorral, 
büszke örömapa-lánya tánccal, majd végül egy váratlan és kegyetlen távozással. Mikor édesapja elvesztéséről beszélünk kezdetben Judit érzései nehezen hozzáférhetőek, nehezen verbalizálja azokat. Majd az üléseink előrehaladtával azt tapasztalom, mikor édesapjáról beszél, gyermekkori emlékeinek felidézése mosolyt csal az arcára. A szomorúságot, a fájdalmakat, mintha felülírná a szeretetteljes emlékezés, amit Judit maga fogalmaz meg. Elmondja, hogy a veszteség miatt minden nap jelen van a fájdalom, de azzal, hogy vissza tud emlékezni és ki tudja mondani az érzéseit édesapjával kapcsolatban most jóleső melegséget érez a szívében.

\subsection{BETEGSÉGREPREZENTÁCIÓK, ÉLETESEMÉNYEK ÉS TÁRSAS KAPCSOLATOK}

Több ülésen keresztül foglalkoztunk azzal, hogy ő maga mit gondol betegségéről és annak hátteréről. Megosztja velem, hogy az egyetemi évei alatt nem figyelt az életmódjára. Úgy gondolja, tünetei kialakulásához az egyetemi évei is hozzájárulhattak. Véleménye szerint sokat bulizott, gyakran kihagyott több étkezést, voltak időszakok, mikor hajnalig tanult, holott nappal is megtehette volna. Úgy érzi, ekkor nagyon lerombolta az egészségét, amit most vissza szeretne állítani. Judit számára nehézséget jelent az egyedüllét. Az egyetemi évei alatt érezte azt először, hogy nem képes egyedül, önmaga lenni. Barátait többször említi üléseink alkalmával. Férjével közös baráti társaságuk van, akikkel rendszeresen összejárnak. Vidám hangulatú találkozásokról, programokról számol be. Barátai tudnak a betegségéről és valódi támaszt nyújtanak számára. Elmondja azt is, hogy úgy érzi, nehezen tud alkalmazkodni a körülötte folyamatosan változó eseményekhez. Pánikszerü tünetekről is beszámol. Tüneteinek kezdetén szorongásoldót és nyugtatót kapott. A betegtájékoztató elolvasása után rosszul lett, több mellékhatást is rövid időn belül produkálni kezdett, pulzusa a félelemtől gyorsan megemelkedett. Kérdésemre elmondja, hogy a pániktünetek jelentkezésekor férje nyugtatta meg. Elmondása szerint az érettségi és az államvizsga időszakában érzett először olyan mértékü stresszt, amivel nem tudott mit kezdeni. Ezekben az időszakokban gyakran gyötörte erős fejfájás. Kivizsgálták, de semmilyen elváltozást nem találtak. Ma már tudja, hogy az akkori fejfájása is a tanulmányai miatti idegeskedések következtében alakult ki, de eszköztelen volt a stresszel szemben. Azt mondja, túl magas elvárásokat támasztott maga elé, amiből nem tudott engedni. Emiatt nagyon stresszesnek és feszültnek érezte magát évekig. Jelenleg házvásárláson gondolkodnak, aminek eseményei, történései szintén nyugtalanítják. Saját magát a művészek között egy merev „figurának” tartja. Az egyetemi évei alatt sokszor tanácsolták neki, hogy legyen lazább, de erős megfelelési vágya volt saját maga és a szülei felé. Elmondása szerint szeretné „hazavinni” a dicsőséget az édesanyjának, és nehezen viseli, ha valami nem úgy megy, ahogyan azt eltervezte. Úgy látja, ha kicsit is lazábban venné a feladatokat, akkor nem tudna előre lépni és nem haladnának a dolgai az életben. Hozzáteszi, amikor úgy érzi, nem mennek a dolgok, akkor belül sem haladnak a dolgok, nem tud emészteni. Ekkor hasában görcsösséget, 
erős fájdalmat érez. Az elhangzottak alapján arra gondolok, mivel Judit nem tudott hatékonyan megküzdeni az életében fellépő változásokkal, stresszhelyzetekkel, testi tünetei egyre inkább fokozódtak.

Mikor azt kérem tőle, hogyan tudná leírni fájdalmát, azt mondja, görcsös, nyomó fájdalmat érez a gyomrában, mintha nem tudna emészteni. „Nem tudom, mit tudnék kezdeni ezzel a fájdalommal" - mondja. Nehézkesség érzésről, görcsösségről, egy nyomó érzésről számol be a gyomrában, amitől nem tud megszabadulni. Ekkor legtöbbször mély lélegzetvételekkel próbálja megnyugtatni magát vagy masszírozni kezdi a hasát. A csoportos szupervíziós ülés megerősített abban, hogy közös munkánk egyik célja a stressz csökkentése, a megfelelő stresszkezelő technika elsajátítása. Az autogén tréning módszer segítségével hozzásegítem egy olyan mértékủ tudatossághoz, hogy tünetei és stressz szintje felett kontrollt tudjon gyakorolni. A módszer segítségére lehet egy olyan látásmód kialakításában is, amit nem a görcsös megfelelés és a hajszoltság jellemez, hanem önmaga elfogadása és a nyugalom. Judit összefüggést lát a pszichés állapota és a tünetei között, ami meghatározza az együttműködésünk motivációját.

\subsection{A VÁLASZTOTT INTERVENCIÓK, TESZTEK ÉS FELADATOK BEMUTATÁSA}

Üléseink alkalmával az autogén tréning relaxáció rövidített változatát alkalmaztam. A relaxáció a karok, lábak és az egész test elnehezedésének, majd átmelegedésének gyakorlatait, továbbá a szív, a légzés és a has átmelegedésének gyakorlataiból állt. A második ülést követően minden alkalommal gyakoroltuk a relaxációt, melyet megbeszélés követett. Ekkor a gyakorlat során tapasztalt testi érzéseket beszéltük meg és arról kérdeztem, hogy mennyire sikerült ellazulni, hogyan érezte magát a gyakorlatok során, milyen érzések kapcsolódtak a testi folyamatokhoz. Otthoni gyakorlást is kértem, melynek tanulságait a következő alkalmakkor beszéltük meg.

Judit az első néhány gyakorlás alkalmával arról számolt be, hogy a hasára irányuló tudatos figyelem, annak ellazítása és hasának átmelegítése nehezen ment. Úgy érezte, kevésbé tudta átadni magát a gyakorlatnak. A hasi testtáj gyakorlata során átélte annak feszülését, görcsösségét, és a hozzá kapcsolódó testi fájdalmakat. Ezzel kapcsolatban igyekeztem megnyugtatni öt. Elmondtam neki, hogy a relaxáció gyakorlásra épül és az első néhány alkalom a gyakorlatokkal való ismerkedésről szól. A has feszülésének érzéséből jól látszik, hogy a fokozott stressz miatt Judit nehezen tudja hasát ellazítani. Figyelme a feszített, görcsös érzésen van. A gyakorlás elörehaladtával, tudatos figyelmének testrészeihez irányításával azonban egyre inkább sikerült ellazulnia és csökkentenie feszültségét.

A kilenc tételes Rövid Betegségpercepció Kérdőív (BIPQ) a betegség kognitív és érzelmi reprezentációinak gyors azonosítását és értékelését teszi lehetővé (Broadbent et al., 2006; Látos et al., 2021). Judit a kérdőíven 44 pontot ért el, ami magas értéknek bizonyul. A kérdőív tételeire adott egyes válaszok és a végeredmény teljes mértékben egybecseng az által elmondottakkal. Úgy gondolja, betegsége hatással van életére, de nem uralja 
mindennapjait, és a gyógyulás jelentős időt fog igénybe venni. Betegsége és tünetei miatt kifejezetten aggódik, ami érzelmileg jelentős hatást gyakorol rá. Mivel kapcsolatot lát tünetei és pszichés állapota között, úgy véli, érti tüneteit. Tünetei okaként leírja, sokat stresszel és aggodalmaskodik, de véleménye szerint korábbi életmódja is hozzájárult.

A Rövid Betegségpercepció Kérdőíven kívül alkalmaztam még a Spielberger - féle Âllapot- és Vonás Szorongás Kérdőívet (Spielberger et al., 1970) is. Ahogyan azt az üléseink alapján feltételeztem, a kérdőíven Judit nagyon magas pontszámot ért el. Nem csak a pillanatnyi, helyzetből adódó szorongás szintje magas, hanem az arra való hajlam szintje is.

\subsection{A TERÁPIA ELŐREHALADÁSA, A KLIENS ÁLLAPOTÁNAK JAVULÁSA}

A tervezett terápia idejének felénél Judit beszámol arról, hogy az otthoni és az üléseken együtt végzett relaxációs gyakorlatok segítségével egyre inkább el tudja magát lazítani, csökkent a stressz szintje és fokozatosan csökkennek hasi panaszai, fájdalma. A fájdalom fokozatos csökkenésével életminőségének javulása a mindennapokban is érezhető, és ezt párja is visszajelezte neki. Arról számolt be, hogy nyugodtabbnak érzi magát, úgy érzi, nincsen megfeszülve az egész teste. Tünetei feletti kontrollját a relaxáció erősítette és magabiztosabbnak érzi magát. Úgy látja, a betegségéről vallott gondolatainak megbeszélése segítette annak tényleges felismerését, hogy a görcsös hasi fájdalom valójában az életében jellemző görcsös megfelelés szimbóluma. Úgy érzi, azzal, hogy ezeket a gondolatait megbeszélte egy szakemberrel és összefüggéseket fedezett fel, felszabadította magát a stressz alól, melyek következtében nagyobb kontrollt képes gyakorolni tünetei felett. Meglátásom szerint ez elsősorban nyugodtságán látszik, amit vissza is jelzek felé. Nemcsak a relaxációt építette be a mindennapjaiba, hanem a jógát is, ami elmondása szerint szintén hozzásegítette a jelenlegi pozitívállapot kialakulásához. Megtapasztalta azt, ha lelki állapotában pozitív irányú változás áll be, azzal egy időben testi panaszai, tünetei is csökkennek, majd megszűnnek. Szakmai tervekről is beszámolt, melyek célirányosak és reálisak. Szeretné, ha munkahelyén továbbra is elégedettek lennének vele. Közös munkánk végénél jártunk, mikor eljött az ultrahangvizsgálat időpontja. Tartott attól, hogy daganatos vagy gyulladásos elváltozást diagnosztizálnak a vizsgálat során. A vizsgálat eredménye negatív lett. Mikor a vizsgálat lefolyásáról, körülményeiről kérdeztem, nyugodtnak láttam. Arról számolt be, hogy egymaga, kíséret nélkül indult a vizsgálatra, nem hagyta, hogy eluralkodjon rajta a félelem. Miközben erről mesél nyugalmat és kiegyensúlyozottságot látok rajta. Testtartása láthatóan kényelmes, nyugalmat sugall.

Judit háziorvosával többször is konzultáltam közös munkánk előrehaladásáról, annak eredményeiről. A terápia elején Judit néhány alkalommal görcsoldó gyógyszerért jelentkezett háziorvosánál, de ezek a kérések idővel elmaradtak. A háziorvos megnyugodott az esettel kapcsolatban, mert a korábbi találkozások alkalmával sokszor reményvesztettnek, elkeseredettnek látta a pácienst. Örömmel fogadta, hogy Judit a relaxáció segítségével nagyobb kontrollt képes gyakorolni tünetei felett, összefüggést fedez fel lelki 
állapota és tüneteinek jelentkezése között, stressz szintje csökkent, ezáltal életminősége javult, a fájdalom és a stressz már nem nehezíti meg mindennapjait. Háziorvosa így összegezte munkámat: „Gyógyitottál!”

\subsection{AZ ESET LEZÁRÁSA, ÖSSZEFOGLALÁS, KONKLÚZIó}

Kliensemnél kimutatható szervi ok nélkül léptek fel ismételt testi panaszok. Jellemző volt a folyamatos aggódás, múltbéli, fel nem dolgozott trauma, váratlan életesemények miatt kialakuló stresszes, feszült állapot. Lelki állapota és testi tünetei között összefüggést látott, melyet a terápia során sikerült még inkább mélyíteni, tudatosítani. A szervi elváltozást nélkülöző testi fájdalom jelentősen rontotta életminőségét. Tüneteit igyekezett csillapítani (étkezések tervezett ütemezése, masszázs), azonban a fájdalom hátterében álló szorongással, stresszel nem volt képes egyedül megküzdeni. A háttérben egy fel nem dolgozott trauma, továbbá az életben való megfelelés és előrehaladás vágyából fakadó hajszoltság, magas stressz-szint állt. A fellépő fájdalom miatt Judit folyamatosan aggódott. Ezt az állapotot a vérében talált antigén jelentősen fokozta. Elérkezve az ultrahang vizsgálathoz Judit stressz-szintje - az elsajátított relaxáció következtében - már jelentősen csökkent, nyugodtabb volt és hatékonyabban tudta kontrolálni tüneteit. A terápia előrehaladtával tehát a krónikus jellegủ tünet a pszichológiai tényezők feltárásával és feldolgozásával csökkenni kezdett, majd meg is szủnt (flash-érzelmi kapcsolat). Judit korábban többször fontolgatta pszichológus felkeresését. A terápia végén üléseink eredményét összefoglalva elmondta, hogy véleménye szerint a jól irányzott kérdések rávilágítottak számára fontos összefüggésekre. A terápiás kapcsolatban (bálinti elsődleges tapasztalati tér) tapasztalt ítélkezésmentes empátiás kommunikáció hatására pedig olyan belső lelki erőket lett képes mozgósítani önmagában, melyek hozzájárultak elsősorban a lelki, majd a fizikai tüneteinek csökkenéséhez, végül azok megszűnéséhez.

A terápiás üléseink alkalmával Judit szinte alig beszélt férjéről. Megosztott bizonyos információkat, eseményeket, de házasságáról, kapcsolatukról nem beszélt. A terápia során nem jelenítette meg megismerkedésüket, nem jelent meg előttem mint feleség. Férjét támogató társként említette, de nem kaptam betekintést kettőjük egységébe. Ennek ténye elgondolkodtat. Mivel életének ezt az oldalát „nem hozta be” a terápiába, úgy döntöttem nem kérdezem erről. Kérdésként merül fel bennem azonban, hogyan lesz képes megküzdeni az egyedülléttel férje külföldi tartózkodása során. Mivel Judit magabiztosabban, kiegyensúlyozottabban éli életét, ezért bízom abban, hogy képes lesz megbirkózni a jövő hozta nehezebb élethelyzetekkel, váratlan eseményekkel. 


\section{Mire tanít ez az eset?}

A bemutatott eset pontosan rávilágít arra, mennyire fontos az egészség szakpszichológus szakember jelenléte az alapellátásban, és mekkora jelentőségű a gyógyulás folyamatában az, hogy a szakember támogatni tudja a klienst a szakorvosi vizsgálatra történő feszült várakozásban. Judit korábban többször gondolt már arra, hogy tüneteivel pszichológust keressen fel, de a valóságban nem tett azért, hogy eljusson szakemberhez. Jelen helyzetben azonban a szakember a háziorvosi praxisban, helyben volt elérhető.

Az orvosilag nem magyarázott testi tüneteket mutató betegek háziorvosuknál megjelenve döntően az alapellátást terhelik, majd számos szakrendelésre irányítva jutnak el különböző kizárásos diagnózishoz, melyek rendszerint nem azt írják le, hogy mi okozza a testi tünetet, hanem inkább azt, hogy mi nem okozza. Lényeges, hogy a pszichológus támogatni tudja a klienst a szakorvosi vizsgálat igénybevételében, mivel a tüneteket tartós stresszhatások, életvezetési konfliktusok, traumák képezhetik. Éppen ezért ennek a betegcsoportnak a kezelése sokkal eredményesebb az alapellátás szintjén egészség szakpszichológus bevonásával, mint a szakellátásban, ahová a kliens kizárólag különböző diagnózisok keresése céljával kerülhet be. Ezen túl a gyógyítás és gyógyulás folyamata természetesen nem nélkülözheti a személyiség feltérképezését, az alapellátásban nagy számmal előforduló mentális kórképek diagnózisát vagy kizárását, ami alapvetően a klinikai szakpszichológus kompetenciaköre. A jövő praxisközösségeiben tehát nem lehet megkerülni a klinikai szakpszichológiai ellátás és az egészség szakpszichológia ellátás együttműködésének kialakítási folyamatát.

\section{DisZKuSSZIó}

Amikor Juditot háziorvosa hozzám irányította, nagyon örültem annak, hogy felismerte azokat a tüneteket, melyekkel pszichológushoz érdemes a betegét irányítani. Rendkívül pozitív tapasztalás volt számomra látni egy olyan háziorvosi praxist, ahol a háziorvos a gyógyítás során a betegséggel összefüggő pszichés tényezők feltárására is figyelmet fordít. Hazánkban eddig csupán bizonyos időszakokra volt elérhető pszichológiai szolgáltatás az alapellátásban. Nem beszélhetünk tehát egy kiépült, ,jól bejáratott”, akár intézményesített rendszerről, ahol a szakember magabiztosan, a szakmai team stabil tagjaként végezhetne eredményes gyógyító munkát. Ezért egy háziorvosi praxisban dolgozó pszichológusnak rengeteg kihívással, új kompetenciákat igénylő problémahelyzetekkel, feladatokkal kell szembenéznie annak érdekében, hogy az alapellátó szakemberekkel hatékonyan és eredményesen tudjon együttműködni. Az a szakember, akinek lehetősége van háziorvosi praxisban dolgozni, minden bizonnyal tekintheti magát e szakterület úttörőjének. Tisztán kell látnia azt a felelősséget, hogy munkájával ő is hozzájárul az alapellátás fejlesztéséhez és szemléletformálásához. Az, hogy szakmailag önállóan kell 
dolgoznia, információt kell megosztania és fogadnia, folyamatos konzultációkat kell végeznie orvos kollégákkal, munkája sikerét csak részben határozza meg. Fontos, hogy a pszichológus képes legyen elérni saját megbecsültségét. Hitelesen tudja képviselni mindazt a tudást, melyen keresztül egy magasabb szintü többletszolgáltatást képes nyújtani az adott praxisközösség (pl.: betegek, orvos, hozzátartozók) számára. Mindehhez az orvosnak is kellő nyitottsággal kell rendelkeznie. Képesnek kell lennie meghaladni a biomedikális elgondolást, akarnia pszichológussal együtt dolgozni, óvnia saját és kollégái lelki egészségét, továbbá motiváltnak lenni a komplex és költséghatékony ellátásra. Sokféle eszköz áll a pszichológus rendelkezésére arra vonatkozóan, hogy miként képes formálni a praxisban dolgozó szakemberek szemléletét. Például a praxisközösségben dolgozó háziorvosok számára tarthat képzést arról, mikor és milyen panaszok, tünetek esetén küldje a betegét pszichológushoz, hogyan exploráljon a háziorvos ahhoz, hogy eldöntse, pszichológusra van szükség, és miként támogassa betegét abban, hogy felkeresse a szakembert. Fontos a háziorvos arról történő tájékoztatása is, mit kérhet a pszichológustól. Hogyan tudja segíteni a beteget például akut vagy krónikus állapotok esetén vagy miként tud egészségmegőrző, prevenciós munkát végezni a praxisban, milyen eszközökkel, kompetenciákkal rendelkezik és dolgozik. A pszichológus munkavégzéséhez tárgyi feltételekre is szükség van. A bizalmi légkör, diszkréció megteremtéséhez szükséges egy konzultációs szoba, ahol az áthallás kizárt. Fontos, hogy ez a helyiség alkalmas legyen egyéni és csoportos konzultációk megtartására, rendelkezzen a kellemes légkör megteremtését segítő berendezéssel. Lényeges feltétel még a háborítatlanság és a rendszeres rendelési idő biztosítása. Mivel jelenleg a tárgyi feltételek is csak részben vagy egyáltalán nem adottak, a háziorvos kreativitásán vagy inkább nagyvonalúságán múlik, hogyan képes biztosítani a szükséges infrastrukturális feltételeket a pszichológus számára.

Mindezek mellett lényeges annak biztosítása is, hogy a kliens háziorvosi beutaló nélkül, közvetlenül is felkereshesse a pszichológust, amennyiben úgy érzi, hogy erre szüksége van.

\section{IRODALOM}

Bálint, M. (1957). Az orvos a betege és a betegség. Animula.

Balint, E., Norell, J. S. (1973). Six Minutes for the Patient: Interactions in General Practice Consultations. Tavistock Publications.

Broadbent, E., Petrie, K. J., Main, J., Weinman, J. (2006). The Brief Illness Perception Questionnaire. Journal of Psychosomatic Research, 60(6), 631-637.

Brouwer, W., Maeseneer, J., Lehtonen, L., Marušič, D., Thomson, S. (2014). Expert Panel on effective ways of investing in Health (EXPH). Definition of a frame of reference in relation to primary care with a special emphasis on financing systems and referral systems. European Commission.

Csabai, M. (2010). Bálint és a pszichoszomatika. Tárgykapcsolati elvek a testi tünetek kezelésében. Thalassa, 21(2), 33-48.

Csabai, M., Kis, N. (2017). Helyzetelemzés az egészségügyi alapellátás keretében nyújtottszolgáltatásokról egészségpszichológia szakterületen. Kézirat. Nemzeti Népegészségügyi Központ. 
Cseh, B., Dózsa, Cs., Dózsa, K. (2021). Praxisközösségi modellprogramok tapasztalatai és aktualitásuk. (online). Letöltve: 2021.03.20. http://medicalonline.hu/cikk/praxiskozossegi_ modellprogramok_tapasztalatai_es_aktualitasa

Edwards, N., Smith, J., Rosen, R. (2014). The primary care paradox. Report. Letöltve: 2021. 03.01. http://home.kpmg/content/dam/kpmg/nz/pdf/Dec/Theprimarycareparadoxwebready report-kpmg-nz.pdf

Gatchel, R. J., Oordt, M. S. (2003). Clinical health psychology and primary care: Practical advice and clinical guidance for successful collaboration. American Psychological Association.

Gunn Jr, W. B., Blount, A. (2009). Primary Care mental health: a new frontier for psychology. Journal of Clinical Psychology, 65(3), 235-252.

Haas, L. J. (2004). Handbook of primary care psychology. Oxford University Press. (online) https://books.google.li/books?id=lmiP_QXkWnQC\&pg=PR13\&hl=de\&source=gbs_sele cted_pages\&cad $=2 \# \mathrm{v}=$ onepage $\& \mathrm{q} \& \mathrm{f}=$ false

Kovács, M. E., Mészáros, E. (2006). Életminőség és betegségteher a magyar lakosságot érintő leggyakoribb betegségekben a Hungarostudy 2002 adatai alapján. In M. Kopp, M. E. Kovács (Ed.), A magyar népesség életminösége az ezredfordulón (412-419. o.). Semmelweis Kiadó.

Látos, M., Lázár, Gy., Csabai, M. (2021). The reliability and validity of the Hungarian version of the Brief Illness Perception Questionnaire. Orvosi Hetilap, 162(6), 212-218.

Leventhal, H., Meyer, D., Nerenz, D. R. (1980). The common sense representation of illness danger. Contributions to medical psychology, 2, 7-30.

Leventhal, H., Nerenz, D. R., Steele, D. J. (1984). Illness representations and coping with health threats. In A. Baum, S. E. Taylor, J. E. Singer (Ed.), Handbook of psychology and health. Vol. IV. Social psychological aspects of health (219-252. o.). Routledge.

Manolopoulos, S. (2006). Early traumas of psychosomatic patients. Splitting and integration. International Congress Series, 1286, 81-86.

Martos, T., Sallay, V., Papp-Zipernovszky, O., Bodóné Rafael, B., Pintér, J. N., Csabai, M. (2017). A praxisközösségi működés tapasztalatai az egészségpszichológus szemszögéből. Népegészségügy, 95(1), 52-56.

Spielberger, C. D., Gorsuch, R. L., Lushene, R. E. (1970). STAI: Manual for the State-Trait Anxiety Inventory. Consulting Psychologist Press.

Stephanos, S. (1975). The concept of analyticaltreatment for patients with psychosomatic disorders. Psychoterapy and Psychosomatics, 26(3), 178-187.

Stephanos, S. (1980). Analytical Psychosomatics in Internal Medicine. International Review of Psycho-Analysis, 7(2), 219-232.

The British Psychological Society. (é.n.). Health psychology in primary care and community settings. Aguide for GPs and Public Health Practitioners. (online) Letöltve: 2021.04.04 Webhely neve: The British Psychological Society honlapja bps.org.uk

Tiringer, I., Varga, J., Molnár, E. (2007). Krónikus betegek ellátásának egészségpszichológiája. In J. Kállai, J. Varga, A. Oláh (Ed.), Egészségpszichológia a gyakorlatban (1014. o.). Medicina Kiadó.

Torzsa, P., Hargittay, Cs., Kalabay, L. (2017). A szorongás és depresszió jelentősége a családorvosi gyakorlatban. Neuropsychopharmacologia Hungarica, 19(3), 137-146.

28/2017. (X.25.) EMMI rendelet egyes egészségügyi tárgyú miniszteri rendeletek módosításáról.5. melléklet. Letöltés dátuma: 2021.04.04. Webhely neve: Jogszabálykereső.

https://net.jogtar.hu/jogszabaly?docid=A1700028.EMM\&timeshift=20171030\&txtreferer= 00000001.txt 